\title{
Anomali Sistem Presidensial Indonesia (Evaluasi Praktek Politik Parlementarian)
}

\author{
Oleh: Sexio Yuni Noor Sidqi \\ Advocat Pada BT Partnership Jakarta \\ e-mail:kiky law25@yahoo.com
}

\begin{abstract}
The combination on presidential system and multi-political parties, in its practice cannot lead to the formation of a strong government, but rather this lead to the anomaly presidential system and being trapped in the parliamentary system.
\end{abstract}

Keywords: Anomali, Sistem Presidensial, Parlementarian

\section{Pendahuluan}

Hiruk pikuk politik menjelang 2009 semakin eskalatif, diyakini medio 2008 adalah pertarungan sesungguhnya untuk menjaring kuasa pada pemilu 2009. Paket RUU Politik satu persatu telah disahkan oleh DPR dan Pemerintah, diawali dengan UU No. 22 Tahun 2007 mengenai Penyelenggara Pemilu, kemudian UU No. 2 Tahun 2008 tentang Partai Politik, UU No.10 Tahun 2008 tentang Pemilu DPR, DPD dan DPRD. Saat ini tinggal menyisakan 2 RUU yang sedang dibahas di DPR yaitu; RUU Pilpres dan RUU Susduk MPR, DPR, DPD dan DPRD.

Perhitungan dan pertimbangan kandidat-kandidat beserta kekuatan politik pendukungnya jauh-jauh hari sudah didengungkan, antara lain Gus-Dur, Sutiyoso, Wiranto, Sri Sultan Hamengkubuwono X, Megawati Soekarno Putri, Jusuf Kalla, SBY, Yusril Ihza Mahendra dll., secara jelas maupun samar-samar telah menyatakan untuk terlibat dalam kontestasi menuju RI 1 di 2009.

RUU Pilpres yang sekarang sudah mulai dibahas di DPR disadari maupun tidak akan menjadi pertarungan sesungguhnya, sayangnya perdebatan-perdebatan yang muncul di Parlemen mengenai isi RUU 
Pilpres tidak pernah menyentuh substansi pokok permasalahan. Perdebatan masih berkisar di seputar syarat dukungan, syarat pencalonan meliputi pendidikan minimal, kesehatan menyangkut jasmani dan rohani, serta usia, tanpa pernah memperdebatkan mekanisme apa yang bisa mengukur visi-misi atau platform yang akan diusung para calon, batasan dan sumber dana kampanye yang boleh dipergunakan, aturan bagi incumbent yang akan maju kembali, pengaturan penggunaan fasilitas negara dan aturan koalisi dalam mengusung calon. Hal tersebut di atas makin menunjukkan kedangkalan politik yang dipegang para elit, yang menunjukkan politic is flat seperti yang disampaikan Arifin Panigoro (Friedman pernah menyatakan The World Is Flat), para elit politik lebih mementingkan "demokrasi-prosedural" daripada "demokrasi-subtansial".

Pasca otoritarianisme Orde Baru, harapan mendudukkan relasi kekuasaan secara ideal melalui Amandemen UUD 1945 menjadi muara harapan, namun semangat untuk memperbaiki sistem yang ada dengan satu persatu melucuti kekuasaan eksekutif menjadi rancu ketika kita masih sepakat pada bentuk sistem Presidensiil, tetapi perubahan yang terjadi justeru mengarah kepada "quasi-Presidensiil", yang semakin memperkuat positioning parlemen. Inilah yang menjadi pekerjaan rumah kita sekarang. Pertanyaan yang bisa dimunculkan, langkah apa yang seharusnya dilakukan agar anomali sistem presidensiil dan praktek parlementarian dengan sistem multi partai dapat diminimalisir agar tidak menambah kekacauan ketatanegaraan Indonesia pasca amandemen UUD 1945.

\section{Perbandingan Sistem Presidensiil dan Parlementer}

Sejauh ini bisa dikatakan, adanya berbagai macam variasi teori demokrasi telah melahirkan berbagai macam tipe demokrasi. Mazhab Scumpeterian, sering dijadikan rujukan utama dalam menganalisa tipetipe demokrasi yang ada, dari tipe demokrasi yang ada, tak jarang melahirkan konsepsi baru, yang merupakan hasil modifikasi dari tipe asal.

Pembagian yang paling umum dalam melihat tipe demokrasi adalah dipakainya parameter mekanisme penyampaian aspirasi oleh warga masyarakat. Adanya parameter ini pada akhirnya membagi tipe demokrasi menjadi dua yaitu; 1) Demokrasi Langsung; dan 2) Demokrasi Perwakilan. Demokrasi perwakilan ini terbagi lagi menjadi tiga tipe demokrasi yaitu; (a) Demokrasi Parlementer; (b) Demokrasi Presidensil; (c) Demokrasi Campuran. 
Mattew Sughart dan John Carey menjabarkan demokrasi campuran ke dalam tipologi yang lebih detail, yaitu; Presidensial Murni (Amerika Serikat); Presidensial Parlementer (Rusia); Perdana Menteri-Presidensial (Polandia); Parlementer-Presidensial (Austria); Parlementer Murni (Inggris). ${ }^{1}$

Menurut A Rahman Tolleng, dari segi bentuk dasarnya pilihan itu hanya dua, akan tetapi kemudian berkembang menjadi empat: ${ }^{2}$

1. presidensialisme yang didasarkan pada doktrin separation of powers atau lebih tepat menyebutnya separation of institutions.

2. parlementarisme yang didasarkan pada doktrin fusion of powers (peleburan kekuasaan) yang secara umum di atas disebut "supremasi legislatif".

3. semi presidensialisme yang menerapkan eksekutif ganda berupa seorang presiden yang dipilih langsung dan seorang perdana menteri yang bertanggung jawab pada parlemen.

4. bentuk ini masih belum banyak dikenal, disebut consensus democracy dengan Swiss sebagai model. Kekhususan model ini, semua atau sebagian besar partai utama ikut kekuasaan dewan eksekutif dalam suatu koalisi yang luas. Dewan ini dipilih untuk masa jabatan tertentu.

Ciri utama sistem presidensiil adalah presiden (top executive) dipilih untuk suatu periode tertentu dan dilakukan melalui pemilihan langsung. Bentuk pemerintahan ini memungkinkan stabilitas eksekutif. Jika eksekutif dipilih secara langsung maka ia memiliki basis pemilih sendiri sehingga tidak tergantung pada badan legislatif. ${ }^{3}$ Dengan demikian presiden tidak mudah digulingkan oleh parlemen yang mungkin saja menguasai mayoritas parlemen. Namun demikian pemisahan secara tegas kekuasaan presiden (eksekutif) dengan kekuasaan legislatif sering menghalangi pelaksanaan program pemerintah. Khususnya jika parlemen tidak setuju dengan program pemerintah. Jika parlemen dikuasai oleh oposisi maka besar kemungkinan pemerintah akan menjadi pemerintah minoritas. Situasi dimana partai menguasai hak eksekutif maupun legislatif juga mungkin terjadi. Dalam keadaan seperti ini jelas bahwa eksekutif sangat

\footnotetext{
${ }^{1}$ Matthew Soberg Sughart dan John M Carey, "President and Asembly: Constitutional Design and Electoral Dynamics", Cambridge Unversity Press, 1992

${ }^{2}$ A. Rahman Tolleng, "What Next Hubungan Eksekutif-Legislatif?",\# posted dari www. Fordem.org : 15.05.05, 22.45 Wib.

${ }^{3}$ William R Thomson dan Monte Palmer,"The Comparative analysis of Politics", 1978.

${ }^{4}$ G. Bingham Powell, Jr., Contemporary Democracies, dalam jurnal Dephan "Indikator Sistem Politik Demokratis" 2002.
} 
dominan, dominasi eksekutif bukan tanpa bahaya. Karena eksekutif dominan jika terancam kelangsungan pemerintahannya dapat mengubah sistem demokrasi munjadi non demokrasi seperti di Philipina. ${ }^{4}$

Menurut Arend Lipjhart ciri utama dari sistem presidensiil adalah pemisahan cabang-cabang eksekutif dan legislatif, dengan kekuasaan eksekutif berada di luar lembaga legislatif. Ini sangat berbeda dengan sistem parlementer yang dicirikan oleh lembaga legislatif sebagai ajang utama penyusunan undang-undang dan (melalui keputusan mayoritas) kekuatan eksekutif. Definisi paling sederhana mengenai perbedaan kedua sistem itu adalah tingkat independensi relatif eksekutif. Pada sistem presidensiil, eksekutif relatif independen dari legislatif. Pada sistem parlementer, terdapat kesalingtergantungan dan kesalingterkaitan dalam kapasitaskapasitas legislatif dan eksekutif. ${ }^{5}$

Untuk memudahkan pemahaman, mari kita lihat beberapa aspek yang membedakan kedua sistem pemerintahan itu. Aspek-aspek tersebut adalah hubungan kelembagaan, pola rekrutmen, serta pola pengawasan dan pertanggungjawaban.

${ }^{5}$ Lihat, Arend Lipjhart, ed," Parliamentarism versus Presidential Government" (Oxford: Oxford University-Press,1992, dalam Tommy Legowo Makalah "Menyempurnakan Sistem Presidensiil". 
Tabel 1

Perbedaan Sistem Presidensiil dan Parlementer

\begin{tabular}{|c|c|c|}
\hline \multirow{2}{*}{ Aspek } & \multicolumn{2}{|c|}{ Sistem } \\
\hline & Presidensiil & Parlementer \\
\hline $\begin{array}{l}\text { H u b u n g a n } \\
\text { kelembagaan }\end{array}$ & $\begin{array}{l}\text { - Terdapat pemisahan } \\
\text { kekuasaan eksekutif dan } \\
\text { legislatif. Namun tak ada } \\
\text { pemisahan antara jabatan } \\
\text { kepala negara dan kepala } \\
\text { plemerintahan. } \\
\text { - Eksekutif dipegang oleh } \\
\text { presiden sebagai kepala } \\
\text { pemerintahan yang sekaligus } \\
\text { adalah kepala negara. } \\
\text { Kekuasaan legislatif berada di } \\
\text { Parleman. Eksekutif dan } \\
\text { legislatif memiliki kekuasaan } \\
\text { terpisah yang seimbang. } \\
\text { - Sebutan bagi kepala } \\
\text { pemerintahan yang sekaligus } \\
\text { kepala negara adalah } \\
\text { Presiden. Karenanya sistem } \\
\text { ini disebut presidensiil. }\end{array}$ & $\begin{array}{l}\text { - Terdapat pemisahan antara } \\
\text { kepala negara dan kepala } \\
\text { pemerintahan. Namun tak } \\
\text { ada pemisahan antara } \\
\text { kekusaan eksekutif dan } \\
\text { legislatif. } \\
\text { - Baik eksekutif maupun } \\
\text { legislatif berada di } \\
\text { parlemen. Jajaran eksekutif } \\
\text { adalah anggota parlemen. } \\
\text { Karenanya sistem ini } \\
\text { disebut parlementer. } \\
\text { - Kepala pemerintahan } \\
\text { adalah pimpinan kekuatan } \\
\text { mayoritas di parlemen. } \\
\text { Kepala negara hanya } \\
\text { memiliki kekuasaan } \\
\text { simbolik di luar eksekutif } \\
\text { dan legislatif. } \\
\text { - S b u t a n k e p a } 1 \text { a } \\
\text { pemerintahan: perdana } \\
\text { menteriatau prime minister. } \\
\text { Sebutan kepala negara: } \\
\text { presiden, raja, ratu, } \\
\text { gubernurjenderal, dll. }\end{array}$ \\
\hline $\begin{array}{l}\text { Pola } \\
\text { rekrutmen }\end{array}$ & $\begin{array}{l}\text { - Tak ada tumpang-tindih per- } \\
\text { sonal antara lembaga eksekutif } \\
\text { dan legislatif. } \\
\text { - Anggota legislatif dipilih } \\
\text { langsung lewat pemilihan } \\
\text { umum. } \\
\text { - Pimpinan eksekutif (yakni } \\
\text { presiden dan wakil presiden) } \\
\text { dipilih langsung melalui } \\
\text { pemilihan umum. } \\
\text { - Jajaran eksekutif lini kedua } \\
\text { (yakni para menteri) diangkat } \\
\text { oleh presiden. }\end{array}$ & $\begin{array}{l}\text { - Terdapat tumpang-tindih } \\
\text { personal antara eksekutif } \\
\text { dan legislatif. } \\
\text { - Anggota legislatif dipilih } \\
\text { langsung lewat pemilihan } \\
\text { umum. } \\
\text { - Partai dengan kursi } \\
\text { mayoritas di parlemen } \\
\text { membentuk pemerintahan. } \\
\text { Pimpinan partai ini } \\
\text { menjadi perdana menteri. } \\
\text { - Anggota parlemen dari } \\
\text { partai mayoritas itu } \\
\text { menjadi menteri. }\end{array}$ \\
\hline
\end{tabular}




\begin{tabular}{|c|c|c|}
\hline $\begin{array}{l}\text { Pola } \\
\text { pengawasan } \\
\text { dan } \\
\text { pertanggung- } \\
\text { jawaban }\end{array}$ & 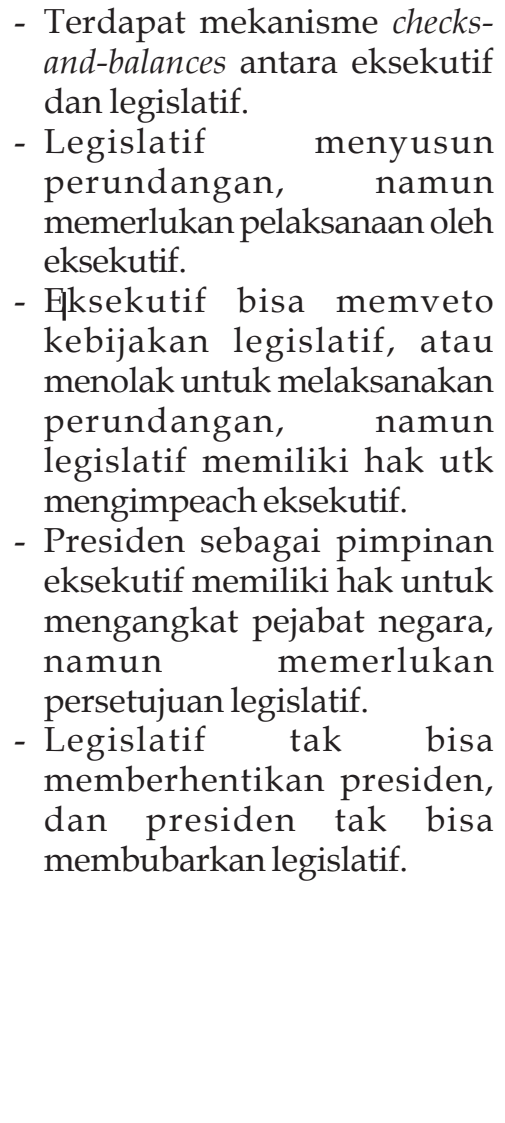 & $\begin{array}{l}\text { - Terdapat mekanisme } \\
\text { pemerintah-oposisi dalam } \\
\text { legislatif. } \\
\text { - Partai kekuatan kedua di } \\
\text { parlemen membentuk } \\
\text { oposisi. Pimpinan partai ini } \\
\text { menjadi ketua oposisi, } \\
\text { anggota-anggota partai } \\
\text { lainnya menjadi anggota } \\
\text { kabinet bayangan sehingga } \\
\text { disebut pula sebagai } \\
\text { menteri-menteri bayangan. } \\
\text { - Kebijakan pemerintah } \\
\text { diperdebatkan di parlemen } \\
\text { dengan pihak oposisi } \\
\text { sesuai dengan lingkup } \\
\text { masing-masing (misal: } \\
\text { perdana menteri dengan } \\
\text { pimpinan oposisi, menteri } \\
\text { keuangan dengan menteri } \\
\text { keuangan bayangan). } \\
\text { - Legislatif } \\
\text { m e m b u b a r k a n } \\
\text { pemerintahan dengan mosi } \\
\text { tidak percaya, dan } \\
\text { mendesakkan pemilu untuk } \\
\text { memilih anggota parlemen } \\
\text { baru. }\end{array}$ \\
\hline
\end{tabular}

Di antara kedua sistem yang sangat berbeda itu, tentu selalu ada sistem gabungan yang mengambil sebagian mekanisme presidensialisme dan sebagian mekanisme parlementarianisme. Jerman adalah contoh negara yang menerapkan semi-parlementarianisme, dimana pimpinan eksekutif dipilih dari kekuatan mayoritas di parlemen-disebut Kanselir (jadi seperti sistem parlementer), namun ia menyusun kabinet sendiri dengan anggota yang tidak harus dari dalam parlemen. Ia bertanggungjawab kepada parlemen, namun tidak bisa begitu saja diberhentikan oleh parlemen. Pimpinan eksekutif ini memegang kekuasaan pemerintahan yang terpisah dari kekuasaan kepala negara yang berada di tangan presiden.

Sistem gabungan lain dapat ditemui di Perancis, dimana presiden dan anggota parlemen dipilih secara terpisah (jadi menerapkan mekanisme presidensiil). Namun presiden hanya menduduki jabatan kepala negara. Dialah yang kemudian akan mengangkat perdana menteri selaku kepala 
pemerintahan, serta mengangkat para menteri anggota kabinet. Parlemen tidak bisa memberhentikan presiden, namun bisa membubarkan kabinet dan memberhentikan perdana menteri. Sementara itu presiden bisa membubarkan dewan perwakilan rakyat, namun tidak bisa membubarkan senat. ${ }^{6}$

\section{Tinjauan Historis Pengalaman Parlementer}

Seringkali negara "baru" memulai kehidupan politiknya sebagai negara merdeka dengan suatu sistem yang mirip dengan sistem negara "induknya", yaitu bekas penjajahnya, terutama kalau proses pemerdekaan itu berdamai. Peniruan seperti itu lebih mudah diterima di negara induk, sedangkan elit terpelajar di negara baru merasa bahwa dia menjalani ujian terakhir dari proses pendidikan politik di zaman penjajahan. Rumusan lain: birokrasi kolonial sudah lama "menghukum" elit bumiputera bahwa dia tidak sanggup memerintah negaranya secara ideal, yaitu sesuai dengan sistem yang berlaku di metropole: dengan menerima dan berusaha melaksanakan sistem itu pasca-kemerdekaan, elit baru membuktikan bahwa kaum kolonial itu salah.

Di Indonesia prosesnya lebih rumit. Cetak-biru (blue print) pertama untuk negara Indonesia merdeka disusun waktu Jepang belum kalah, sehingga UUD 1945 justru lebih bereaksi negatif terhadap sistem parlementer Belanda dari pada meniru. Yang ditekankan adalah dominasi eksekutif; partai, kalau ada, diharapkan partai tunggal; pemilu tidak disebut, begitu juga dengan hak-hak individu (Muatan dalam Konstitusi). ${ }^{7}$ Hal ini bisa dilihat dari hasil formulasi BPUPKI-PPKI dalam merumuskan UUD 1945 yang isinya sangat dominan kekuasaan eksekutifnya, walaupun pro-kontra di PPKI juga terjadi dalam pilihan sistem pemerintahan, apakah akan menggunakan sistem presidensiil atau sistem parlementer. Ada yang berpandangan sistem parlementer lebih tepat untuk negara yang baru merdeka, karena sistem parlementer lebih dinamis dalam mengakomodir perkembangan politik yang ada.

\footnotetext{
${ }^{6}$ Abdul Gaffar Karim, “Kabinet Bayangan ,7/09/2007.

${ }^{7}$ Lance Castles, "Pengalaman Demokrasi Liberal di Indonesia", (1950-1959) dalam Seminar "Pendidikan Demokrasi dan Dialog Sipil-Militer", Tanggal 11 Juni 1998 dalam Sexio Yuni Noor Sidqi, Partai Politik dan Transisi Demokrasi di Indonesia (Studi Perkembangan Partai Politik dari Era Orde Baru-Reformasi), Skripsi, Fakultas Hukum Universitas Islam Indonesia, Yogyakarta, 2005, hlm. 101.
} 
Perkembangan setelah itu memperlihatkan pergeseran arus besar kekuasaan, tanpa mengubah UUD 1945 sistem pemerintahan negara kita dalam waktu 3 bulan berubah menjadi sistem parlementer, yaitu ketika Kelompok Sjahrir berhasil mendorong perubahan dan perluasan fungsi Komite Nasional Indonesia Pusat (KNIP) dengan dibentuknya Badan Pekerja (BP-KNIP) yang akan berfungsi seperti Parlemen, bahkan Sjahrir berhasil meyakinkan Pemerintah (Soekarno-Hatta) untuk "share" dalam bidang pemerintahan dengan memberikan kewenangan pemerintahan kepada KNIP yang akan membentuk kabinet (kabinet mulai dipimpin Sjahrir pada November 1945), sekali lagi ini menunjukkan bahwa pendukung sistem Parlementer jeli dalam memanfaatkan momentum ditengah kondisi negara yang belum stabil. ${ }^{8}$

Perubahan di atas diformulasikan oleh Pemerintah yang mengeluarkan Maklumat Pemerintah tanggal 3 November 1945 tentang perubahan peran BPKNIP yang ditandatangani oleh Wakil Presiden Moh.Hatta (adanya maklumat pemerintah semakin memperkuat sistem parlementer, meskipun kenyataannya belum pernah dilaksanakan Pemilu, baru direncanakan pada tahun 1946). Dalam maklumat itu antara lain disebutkan; berhubung dengan usul Badan Pekerja Komite Nasional Pusat kepada Pemerintah supaya diberikan kesempatan kepada rakyat seluasluasnya untuk mendirikan partai politik, dengan restriksi, bahwa partaipartai itu hendaknya memperkuat perjuangan kita mempertahankan kemerdekaan dan menjamin keamanan masyarakat. Pemerintah menegaskan pendiriannya yang telah diambil beberapa waktu lalu (Maklumat Pemerintah No X tanggal 16 Oktober 1945 tentang pembentukan partai-partai politik) :

a. Pemerintah menyukai timbulnya partai-partai politik, karena dengan adanya partai-partai itulah dapat dipimpin ke jalan yang teratur segala aliran politik yang ada dalam masyarakat.

b. Pemerintah berharap supaya partai-partai telah tersusun, sebelum dilangsungkan pemilihan anggota Badan-Badan Perwakilan Rakyat pada bulan Januari $1946 .^{9}$

${ }^{8}$ J.D. Legge, “Kaum Intelektual dan Perjuangan Kemerdekaan: Peranan Kelompok Sjahrir", Jakarta, Pustaka Utama Grafiti, 1993, hlm. 179-182.

${ }^{9}$ Dhaniel Dhakidae, dalam "Partai-partai Politik Indonesia: Ideologi, Strategi dan Program", Tim Litbang Kompas-Ed. Pemilu, Cet.1.-Jakarta : Kompas, 1999, Bab 1 hlm. 8. 
Sesudah dikeluarkannya Maklumat Pemerintah No X tersebut, secara resmi berdirilah beberapa partai politik yang secara kronologis dapat disebutkan sebagai berikut; (1) Masyumi, Berdiri pada 7 November 1945, dengan ketua Dr.Soekiman Wirjosandjojo; (2) PKI, \& November 1945, ketua Mr. Moh Jusuf; (3) PBI, 8 November 1945, ketua Njono; (4) Partai Rakyat Jelata, 8 November 1945, ketua Sutan Dewanis; (5) Parkindo, 10 november 1945, Ketua Dr. Probowinoto; (6) PSI, 10 November 1945 Ketua Mr. Amir Sjarifuddin; (7) PRS, 20 November 1945, ketua Sutan Sjahrir; (8) Partai Katholik, 8 Desember 1945, Ketua I.J Kasimo; (9) Permai 17 Desember 1945, ketua J.B. Assa; (10) PNI, 29 Januari 1946, sebagai gabungan dari PRI, Gerindo dan Serikat Rakyat Indonesia dengan ketua Sidik Djojosoekarto. ${ }^{10}$

Berdirinya partai-partai politik tersebut menunjukkan dukungan yang kuat akan sistem parlementer (karena sistem multipartai mafhum diterapkan di negara yang menganut sistem parlementer), sekaligus "mengubur" keinginan Soekarno untuk membentuk partai tunggal-partai negara (Staaats Partij). Keinginan Soekarno tersebut terilhami dari pengalaman Jepang dalam memobilisasi politik, serta kekhawatiran konflik antara partai akan menimbulkan perpecahan yang tidak terelakkan, dalam suatu republik yang baru dan masih rapuh, hal itu merupakan ancaman bagi persatuan nasional.

Setelah Republik sempat menghadapi Agresi Militer Belanda I dan II, serta menjadi Republik Indonesia Serikat (RIS-secara singkat) dengan diberlakukanya Konstitusi RIS 1949, Indonesia menjadi Negara Kesatuan lagi pada tahun 1950. Momentum pemberlakuan UUDS 1950 yang didalamnya secara jelas dalam Pasal 51 ayat 2 menyatakan "Sesuai dengan anjuran pembentuk Kabinet itu, Presiden mengangkat seorang dari padanya menjadi Perdana Menteri dan mengangkat Menteri-menteri yang lain", maupun dalam Penjelasan UUDS 19503 (f) "Dewan Menteri harus bersifat Kabinet Parlementair", teks di atas semakin memperkuat sistem Parlementer, dan Indonesia mulai mengarungi era demokrasi liberal .

Demokrasi liberal yang diwarnai dengan jatuh bangunnya kabinet kalau dirangkum, adalah sebagai berikut: Kabinet Sjahrir (14 November 1945-12 Maret 1946, 12 Maret-2 Oktober 1946, 2 Oktober 1946-17 Juni 1947); Kabinet Amir Syarifuddin (3 Juli-11 November 1947, 11 November 1947-

${ }^{10}$ F.S.Swantoro, dalam Bantarto Bandoro, J.Kristiadi, Mari Pangestu dan Onny S.Prijono (penyunting),"Refleksi Setengah Abad Kemerdekaan Indonesia", Ctk. Pertama, CSIS, Jakarta, 1995, hlm. 163. 
29 Januari 1948); Kabinet Hatta (29 Januari 1948-4 Agustus 1949); dilanjutkan dengan sistem demokrasi liberal (1950-1959) Kabinet Natsir (6 september 1950 - 27 April1951), Kabinet Soekiman (27 April 1951 - 3 April 1952), Kabinet Wilopo (3 April 1952 - 30 April 1953), Kabinet Ali Wongso (30 Juli 1953 - 12 Agustus 1955), Kabinet Burhanudin Harahap (12 Agustus 1955 - Maret 1956), Kabinet Ali Sastroamidjojo (24 maret 1956 - 14 maret 1957) dan Zaken Kabinet, Kabinet Djuanda (9 April 1957 - 10 Juni 1959.11

Pada masa itu, banyak yang menyebut era demokrasi Parlementer, adalah masa keemasan kehidupan partai politik di Indonesia, yang mana partai dapat memfungsikan dirinya sebagai bagian dari kekuatan politik yang harus bertarung memperebutkan kekuasaan, Pemilu 1955 yang dilaksanakan untuk memilih anggota DPR (29 September 1955) dan Konstituante (15 Desember 1955) berjalan sangat demokratis dengan melahirkan 4 kekuatan politik utama yaitu; 1. PNI (23,3\%), 2. Masyumi $(20,9 \%), 3$. PNU $(18,4 \%)$, dan 4. PKI $(15,4 \%)$, kemudian dibentuklah Kabinet Koalisi pertama dari hasil Pemilu 1955 yang dipimpin oleh Ali Sastroamidjojo (24 maret 1956 - 14 maret 1957).

Konstituante yang bertugas untuk merumuskan Konstitusi pun mulai bersidang, terjadi perdebatan panjang didalamnya mengenai Dasar Negara -yang mengingatkan kita pada perdebatan dalam perumusan awal di BPUPKI tentang dasar negara dalam UUD 1945. Sayangnya semangat demokrasi subtantif menjadi sirna dengan dikeluarkannya Dekrit Presiden 5 Juli 1959, sebuah keputusan presiden untuk membubarkan Konstituante dan pernyataan kembali ke UUD 1945 (yang sampai sekarang masih meninggalkan tanda ?). Presiden Soekarno berpandangan kondisi bangsa yang carut marut dengan jatuh bangunnya kabinet, banyaknya pemberontakan-pemberontakan di daerah, serta mulai munculnya ketidakpuasan masyarakat akan kinerja partai politik, merupakan akibat dari penerapan demokrasi liberal-yang ditopang partai politik yang fragmentaris.

Dengan dikeluarkannya Dekrit Presiden 5 Juli 1959, era Demokrasi Terpimpin dengan Soekarno menjadi sentral pun tersaji di medio 19591966, yang meminjam istilah Ismail Sunny sebagai kekuasaan negara

${ }^{11}$ Ign Ismanto, J.Kristiadi, Indra.J.Piliang...(et al) ; Penyunting T.A Legowo, Y.Subagyo, Sutomo...(et. al),"Pemilihan Presiden Secara Langsung 2004; Dokumentasi, Analisis dan Kritik" ctk pertama Jakarta :Kedeputian dinamika Masyarakat Menristek RI,2005 Kerjasama dengan Departemen Politik dan Perubahan Sosial CSIS. 
bukan lagi mengacu kepada democracy by law, tetapi democracy by decree. Personalisasi kekuasaan dengan menebar benih anti partai seolah menjadi "resep" pengganti Demokrasi Parlementer, hal tersebut memuluskan langkah Soekarno untuk mewujudkan imajinasi politiknya di waktu muda yakni mengawinkan tiga ideologi sekaligus (nasionalis,Islam,dan komunisNASAKOM) dalam kendali otoritarianisme kepemimpinannya.

Otoriterianisme pemerintahan Presiden Soekarno makin jelas ketika pada 4 Juni 1960 ia membubarkan DPR hasil Pemilu 1955, setelah sebelumnya dewan legislatif itu menolak RAPBN yang diajukan pemerintah. Presiden Soekarno secara sepihak dengan senjata Dekrit 5 Juli 1959 membentuk DPR-Gotong Royong (DPR-GR) dan MPR Sementara (MPRS) yang semua anggotanya diangkat presiden. Pengangkatan keanggotaan MPR dan DPR, dalam arti tanpa pemilihan, memang tidak bertentangan dengan UUD 1945. Karena UUD 1945 tidak memuat klausul tentang tata cara memilih anggota DPR dan MPR. Tetapi, konsekuensi pengangkatan itu adalah terkooptasi-nya kedua lembaga itu di bawah presiden. Padahal menurut UUD 1945, MPR adalah pemegang kekuasaan tertinggi, sedangkan DPR neben atau sejajar dengan presiden. ${ }^{12}$

Di sini menunjukkan bahwa UUD 1945 yang menempatkan kekuasaan eksekutif sangat absolut telah disalahgunakan bahkan Presiden Soekarno diangkat sebagai Presiden seumur hidup pada 1963 oleh MPRS yang dipilih dirinya sendiri. Masa demokrasi terpimpin menjadi wahana bagaimana tiga kekuatan politik (Soekarno, TNI-AD, PKI) "berkolaborasi dan saling tarikmenarik kepentingan", dengan menegasikan kekuatan politik yang lain (parpol-selain PKI) hingga mencapai klimak (titik kulminasi) dengan terjadinya pemberontakan G-30-S/PKI yang kemudian tidak saja mengakhiri kiprah politik Soekarno dan PKI, tetapi juga menjadi awal dari adanya pergantian kepemimpinan di level yang paling atas. Era demokrasi terpimpin pun berakhir seiring dorongan pembaruan dan perbaikan serta harapan baru dari masyarakat atas berbagai permasalahan akut yang menimpa bangsa.

\section{Problem Konstitusi dan Praktek Politik Parlementarian}

Naiknya Soeharto dalam tampuk kepemimpinan setelah Soekarno turun, menandai dimulainya sebuah orde yang disebut dengan Orde Baru - untuk

${ }^{12}$ M. Rusli Karim,"Perjalanan Partai Politik Di Indonesia; Sebuah Potret Pasang Surut", Ctk 3, Jakarta; Rajawali Press, hlm. 143. 
membedakan dengan Orde Demokrasi Terpimpin yang sering disebut Orde Lama - dengan janji akan melaksanakan Pancasila dan UUD 1945 secara murni dan konsekuen. Orde baru mulai menancapkan kekuasaannya, praktek politik orde baru yang menempatkan kekuatan eksekutif (eksekutif heavy) mendominasi pilar yang lain telah menimbulkan efek traumatis, dengan mendogmakan Pancasila \& UUD 1945 Presiden tidak bisa dikontrol oleh parlemen. Kekuasaan yang melekat secara personal telah menjelma menjadi kekuatan tiran yang efektif dan ditakuti, ditopang oleh mesin ABG (ABRI, Birokrasi dan Golkar) menjadikan Soeharto bisa bertahta selama 32 tahun. Jargon developmentalisme dan pertumbuhan ekonomi yang dicetuskan oleh Soeharto telah menyandera demokrasi, dengan menyebut yang berbeda dan kritis adalah subversif dan komunis serta memenjarakannya sebagai tapol/ napol, angin perubahan dengan adanya krisis ekonomi tahun 1997 telah merubah semuanya, Soeharto-sosok yang teguh berkuasa pun tumbang di hadapan perjuangan mahasiswa pada 21 Mei 1998.

Jatuhnya Presiden Soeharto merupakan puncak dari perjuangan Reformasi 1998 yang menginginkan perubahan atas status quo yang telah berkuasa selama 32 tahun. Reformasi yang melahirkan 6 visi yang harus diperjuangkan, salah satunya adalah amandemen UUD 1945. Rezim Habibie yang "singkat" menyambut hal itu dengan mempercepat proses Pemilu, Pemilu direncanakan 1 tahun kemudian (1999), dengan dibentuknya tim 7 yang bertanggung jawab membuat paket UU Politik dari Pemerintah, maupun kemudian tim 11 (tim persiapan pembentukan KPU) yang menyeleksi partai politik peserta Pemilu 1999. Setelah Pemilu, MPR dibawah kendali Amien Rais mengusung Amandemen UUD 1945. Amandemen dilaksanakan dalam 4 jilid (dikenal perubahan pertamakeempat, 1999-2002), pasca turunnya Soeharto sebagai Presiden. Isu utama perubahan dalam UUD 1945 adalah bagaimana membatasi kekuasaan eksekutif, mekanisme checks and balances harus dikembalikan dengan menempatkan Parlemen sebagai kontrol pemerintah, adanya pembatasan masa jabatan Presiden dengan maksimal dua periode menjabat, serta dipilihnya mekanisme pemilihan presiden secara langsung. Sayangnya desain perubahan UUD 1945 ini tidak disertai grand design yang utuh, karena perubahan yang dilaksanakan kemudian justru meninggalkan bom waktu dalam perjalanan ketatanegaraan ke depan, salah satunya yaitu relasi Pemerintah dan Parlemen yang tidak seimbang ditengah sistem Presidensiil yang tetap dipilih. 
Diintrodusirnya Pasal 6A ayat (1) UUD 1945 yang menetapkan "Presiden dan Wakil Presiden dipilih dalam satu pasangan secara langsung oleh rakyat" dalam perubahan UUD 1945, merupakan pilihan yang strategis dan signifikan sekaligus koreksi atas praktek ketatanegaraan masa lalu, yang menempatkan MPR sebagai perwakilan seluruh rakyat Indoensia, yang dengan kekuasaan yang diberikan UUD 1945 berhak memilih dan melantik Presiden.

Secara teoretis ada dua sistem besar dalam pemilihan presiden secara langsung. Sistem pertama biasa disebut dengan first past the post, ketika presiden terpilih ditentukan berdasarkan perolehan jumlah suara terbanyak. Sistem ini dipakai oleh sejumlah negara seperti Meksiko, Kenya, Filipina, Korea Selatan, Taiwan, dan Zimbabwe. Dalam negara yang menganut sistem multipartai sering kali seorang presiden terpilih hanya menang tipis, sehingga bisa dianalogikan dengan pacuan kuda sehingga seekor kuda bisa menang jika hidungnya menyentuh garis finis terlebih dulu (Robert A. Dahl, 2003). ${ }^{13}$

Kasus seperti ini terjadi dua kali di Filipina, pertama pada 1992 ketika Fidel V. Ramos mengalahkan Miriam Santiago dengan margin kurang dari 1 persen dan 12 tahun kemudian Presiden Gloria Macapagal Arroyo mengalahkan Fernando Poe Jr. dengan perbedaan suara sekitar 2 persen.

Sistem kedua dikenal dengan sistem pemilihan presiden dua putaran (two round system/Run Off). Apabila dalam pemilihan putaran pertama tidak ada pemenang mayoritas, diadakan pemilihan putaran kedua, biasanya antara dua calon dengan perolehan suara terbanyak. Sistem seperti ini dianut oleh negara seperti Prancis dan sebagian besar negaranegara di Amerika Latin. Suara mayoritas yang dibutuhkan untuk menang biasanya bervariasi di masing-masing negara. Semisal di Kosta Rika, untuk menang dalam putaran pertama seorang calon presiden cukup memperoleh 40 persen suara, sedangkan Argentina mematok angka 45 persen sebagai suara mayoritas.

Perubahan Ketiga UUD 1945 telah menentukan bahwa Indonesia menganut sistem pemilihan presiden dua putaran. Pasal 6A Ayat (3) UUD 1945 mempersyaratkan bahwa pasangan calon presiden dan wapres yang mendapatkan suara lebih dari 50 persen dari jumlah suara dalam pemilu, dengan sedikitnya 20 persen suara di setiap provinsi yang tersebar di lebih dari setengah jumlah provinsi di Indonesia, dilantik menjadi presiden dan wapres.

${ }^{13}$ Hendri Kuok, "Bom Waktu Sistem Pemilihan Presiden Dua Putaran", Kompas, Jumat, 17September 2004, bandingkan dengan Smita Notosusanto, Usulan Pemilihan PresidenLangsung,www.cetro.or.id, 6 mei 2005. 
Dalam hal tidak ada pasangan capres dan wapres terpilih, dua pasangan calon yang memperoleh suara terbanyak pertama dan kedua dalam pemilu, dipilih oleh rakyat secara langsung dan pasangan yang memperoleh suara terbanyak dilantik sebagai presiden dan wapres. Hal itu tertuang dalam Pasal 6A Ayat (4) UUD 1945.

Para wakil rakyat di MPR mungkin berpikiran bahwa sistem dua putaran bisa mengeliminasi keresahan sosial di masyarakat pascapemilihan presiden secara langsung. Apabila sistem first past the post yang dipakai, potensi konflik sosial akan cukup besar karena pendukung calon presiden yang kalah akan merasa tidak puas dengan kekalahan yang tipis atau pihak yang kalah akan mempertanyakan legitimasi presiden terpilih yang tidak mengantongi suara mayoritas.

Niat baik dari para legislator kita untuk meminimalisasi konflik sosial tidak berarti membawa hasil yang baik, karena sistem dua putaran dengan kombinasi sistem multipartai juga mengandung sejumlah kelemahan. Sistem pemilihan presiden dua putaran cenderung menghasilkan sebuah pemerintahan yang minoritas dan skenario deadlock dalam hubungan antara pemerintah dan parlemen.

Besar kemungkinan seorang presiden terpilih berasal dari partai yang minoritas di parlemen dan ketika parlemen dikuasai oleh kekuatan politik yang berbeda, akan timbul ketidakharmonisan antara parlemen dan pemerintah. Sebagai contoh dalam Pemilu 1990 di Peru, Alberto Fujimori memperoleh 56 persen suara dalam pemilihan presiden putaran kedua, tetapi partainya hanya menguasai 19 persen kursi di Majelis Rendah. Setelah selama dua tahun terus-menerus parlemen menentang program Reformasi Ekonomi Pemerintah, Presiden Fujimori dengan dukungan dari militer mengambil tindakan membubarkan parlemen.

Di sisi lain, sistem dua putaran cenderung melahirkan sebuah koalisi dadakan yang tidak bersifat permanen. Bukti nyata bisa kita lihat di Brasil dalam pemilihan presiden 1994. Dalam pemilihan putaran pertama, calon presiden Fernando Cardozo dari PSDB (Brazilian Social Democratic Party) tiba-tiba mendapat sokongan dari PPR (The Progressive Renewal Party) dan PMDB (Party of the Brazilian Democratic Movement) - kedua partai tersebut memutuskan mengabaikan kandidat mereka sendiri setelah melihat Cardozo berada di atas angin. ${ }^{14}$

\footnotetext{
${ }^{14}$ Hendri Kuok, Op.Cit.
} 
Setelah Cardozo terpilih sebagai presiden, PPR yang mendapat jatah satu menteri di kabinet Cardozo ternyata tidak mendukung pemerintah di parlemen. Sementara itu, PMDB yang mendapat jatah dua menteri juga tidak bisa memaksimalkan suara mayoritas mereka di parlemen untuk mendukung pemerintah karena PMDB mengalami krisis internal partai.

Dua pengalaman di atas tergambar ketika pasangan Susilo Bambang Yudhoyono-Jusuf Kalla memenangi pemilihan presiden putaran kedua dengan mengalahkan pasangan Megawati Soekarnoputri-Hasyim Muzadi, modal SBY-Kalla yang didukung Koalisi Partai Demokrat, Partai Bulan Bintang, PKPI, PKS (bergabung pada putaran kedua) sering disebut dengan koalisi Kerakyatan berhadapan dengan Koalisi Kebangsaan yang mensupport Mega-Hasyim, yang terdiri dari PDIP, Golkar, PPP, PDS. Sudah terlihat secara kasat mata terjadi ketimpangan dalam basis dukungan dari parlemen (governing support), apalagi statement dari koalisi kebangsaan yang menyatakan akan bersikap oposisi di Parlemen-bisa dibayangkan kekuatan minoritas pendukung SBY-Kalla dihadapkan pada tembok kokoh di Parlemen, niscaya kemungkinan efektifitas kebijakan pemerintah akan terhambat di Parlemen. Publik yang berharap akan tersajinya sebuah pertarungan politik yang konstruktif antara Pemerintah dan Parlemen setelah sekian lama disajikan parodi parlemen di era Orde Baru, menjadi sirna ketika banyak anggota koalisi Kebangsaan lompat pagar, hal ini tercermin dalam pertarungan perebutan Pimpinan DPR dan MPR, Koalisi Kebangsaan dengan paket; H.R Agung Laksono (Golkar), Soetardjo Soeryogoeritno (PDIP), Muhaimin Iskandar (PKB) dan Zaenal Maarif (PBR), berhadapan dengan paket Koalisi Kerakyatan; Endin AJ Soefihara (PPP), E.E.Mangindaan (P.Demokrat), Ahmad Farhan Hamid (PAN), Ali Masykur Musa (PKB), maupun perebutan kursi MPR yang pada waktu itu paket Koalisi Kebangsaan adalah; Ir Sutjipto (PDIP), Theo L Sambuaga (Golkar), Sarwono Kusumaatmaja (DPD), Irman Gusman (DPD), dan Paket Koalisi Kerakyatan; Hidayat Nurwahid (PKS), AM Fatwa (PAN), Moeryati Sudibyo (DPD), Aksa Mahmud (DPD), dengan hasil pimpinan DPR dimenangkan oleh Koalisi Kebangsaan dan Pimpinan MPR dimenangkan oleh Koalisi Kerakyatan.

Spektrum politik pun makin bergeser menjelang Munas Partai Golkar di Bali pada akhir tahun 2004, ketika SBY memberi ijin kepada Jusuf Kalla untuk turun gelanggang dan maju dalam pertarungan merebutkan posisi Ketua Umum Golkar, hal ini diharapkan dapat merubah sikap Golkar di parlemen. Kemenangan Kalla yang pada waktu itu didukung semua elemen dan tokoh senior Golkar(oleh Kubu Akbar merasa dikeroyok dari 
8 penjuru mata angin) membuat posisi Golkar berbalik arah-dengan menyatakan keluar dari koalisi kebangsaan dan mendukung penuh duet SBY-Kalla, sejak saat itu harapan akan adanya perubahan warna di parlemen yang kritis menjadi sia-sia.

Duet SBY-Kalla yang mendapatkan 69.266.350 juta suara atau setara dengan 60, $62 \%$ pada putaran kedua ${ }^{15}$ dalam praktiknya ternyata tidak percaya diri dalam menahkodai republik, terbukti format Koalisi diperluas dengan menyertakan PPP, PAN, PKB dan Golkar dalam pembagian portofolio kabinet (hampir separuh anggota kabinet adalah wakil parpol atau punya afiliasi dengan parpol) dengan hanya menyisakan PDI-P sebagai kekuatan oposisi. Harapan memperluas koalisi di satu sisi adalah positif sebagai bekal back up di parlemen dalam mengawal kebijakan pemerintah, namun dasar pembentukan koalisi yang dibangun hanya berdasarkan pragmatisme politik tanpa mengedepankan platform maupun kesaman visi adalah absurd. Absurditas di sini tergambar jelas ketika orientasi partai politik di Indonesia masih haus akan kekuasaan, harapan memperkuat sistem presidensiil yang efektif pun hanya jadi savana di padang politik, terbukti meskipun Pemerintah bisa dikatakan menguasai suara parlemen namun dalam praktiknya sering kali "diganggu" oleh parlemen.

Hal tersebut di atas menjadi rancu ketika kita sepakat pada bentuk sistem pemerintahan Presidensiil, akhirnya yang tersaji adalah pemerintah tidak dapat efektif melaksanakan mandatnya-karena sibuk dengan olah DPR, alih-alih tercipta hubungan checks and balances, relasi yang terjadi adalah DPR menjelma menjadi lembaga super yang seolah-olah kapanpun siap menerkam dan menggergaji kebijakan Pemerintah.

Kasus mutakhir terjadinya pro-kontra di parlemen mengenai rencana kenaikan harga BBM yang diterapkan oleh pemerintah pada 24 Mei 2008. Dalam pidato pembukaan paripurna Ketua DPR Agung Laksono yang notabene menjabat Wakil Ketua Umum Partai Golkar (salah satu partai penyokong pemerintah) menolak kebijakan kenaikan harga BBM, padahal DPR melalui alat kelengkapannya telah menyetujui perubahan APBNP 2008 yang diajukan pemerintah. Logikanya ketika DPR telah menyetujuinya, maka tidak ada persoalan dalam kebijakan kenaikan harga BBM, meskipun DPR tetap harus mengkritisi dan menawarkan alternatif lain yang bisa ditempuh selain kebijakan non-populis menaikkan harga BBM, misalnya menggenjot sektor pajak progresif, negosiasi hutang,

\footnotetext{
${ }^{15}$ Ign Ismanto, J.Kristiadi, Indra.J.Piliang (et al); Loc.cit.
} 
maupun penghematan belanja rutin dinas. Seperti diketahui, BBM adalah salah satu penggerak utama dalam mata rantai ekonomi, sekali naik dia akan membawa efek domino ke sektor yang lain, apalagi masih dipakainya "resep-BLT" yang rawan penyimpangan dan tidak mendidik masyarakat. Hal di atas membuktikan terjadinya kerancuan dalam sistem presidensiil yang kita terapkan, sekaligus fragmentasi antar "pendukung pemerintah". Kalau niat awal menolak kenaikan harga BBM adalah untuk membela kepentingan rakyat-maka patut kita dukung secara masif, sayangnya ini ditengarai hanya menjadi komoditas politik sesaat (etalase bagi parpol) menjelang Pemilu 2009. Begitupun yang terjadi dengan partai politik yang lain, PAN, PKB dan PKS, ketiga partai ini juga sering kali mengambil kebijakan berbeda di Parlemen (bahkan untuk kenaikan BBM, PKB mengusulkan hak angket yang bisa mengarah pada "Pemakzulan Presiden"), dengan sering mengganjal kebijakan pemerintah, mulai dengan menggunakan hak-hak DPR (terutama interpelasi dan angket), meminjam istilah Arbi Sanit - Partai Politik pendukung Pemerintah telah melakukan pengkhianatan. ${ }^{16}$ Di sini mereka menggunakan "Politik dua muka" yaitu kritis di parlemen namun akur di kabinet. Hal tersebut dilakukan hanya untuk kepentingan pencitraan partai kepada konstituen, seolah-olah mereka kritis-namun sejatinya adalah manipulatif karena hanya untuk bargaining politik dengan pemerintah (lihat penyelesaian secara adat melalui lobi Darmawangsa). Mengapa demikian? Memiliki wakil di Kabinet adalah sebuah keuntungan sekaligus investasi politik, karena dua sumber resources ada di sana-yaitu Sumber Daya Manusia dan Dana, sehingga partai politik akan sekuat tenaga mempertahankan wakilnya disana, tidak peduli apakah memakai ukuran etis maupun tidak, semua itu demi satu tujuan untuk menambah "bahan bakar" menghadapi pemilu 2009. Semua ini bermula dari kekaburan format koalisi jangka pendek yang dibangun, meminjam istilah Denny Indrayana, yang terjadi sekarang awalnya karena Multikohobitasi antara SBY dan Kalla dengan basis dukungan Demokrat dan Golkar ${ }^{17}$ yang 'jomplang'.

Menjadi penting di sini kita mendudukkan lagi sistem presidensial yang kuat sesuai dengan UUD 1945, dan hal ini juga terkait dengan sistem kepartaian yang ada. Pasca amandemen UUD 1945 tersaji sebuah pergeseran pendulum kekuasaan, setelah sebelumnya antara 1966 sampai 1998, berlaku

${ }^{16}$ Kompas, 12 Mei 2008, hlm. 3.

${ }^{17}$ Denny Indrayana, “Mendesain Presidensial”, Kompas Senin, 17 Maret 2008. 
sistem pemerintahan untuk negara integralistik dengan konsentrasi kekuasaan amat besar pada Presiden (too strong presidency), kemudian posisi MPR sebagai pemegang kedaulatan negara tertinggi dan sebagai perwujudan dari rakyat dihapus dan badan legislatif ditetapkan menjadi badan bikameral dengan keuasaan yang lebih besar (strong legislative). ${ }^{18}$ Hal ini merupakan akibat dari pengalaman praktek politik masa lalu yang menyimpang, sehingga menimbulkan traumatis akan kekuasaan eksekutif yang telampau besar. Pengalaman era Orde Lama maupun Orde Baru telah menggambarkan bagaimana tafsir atas keuasaan eksekutif (dalam UUD 1945) yang luas menjadi racun dan ancaman bagi demokrasi.

Bahwa Presiden tidak dapat membubarkan DPR dan DPR tidak dapat menjatuhkan Presiden adalah esensi dasar dari Sistem Presidensiil (Parlemen hanya dapat menuntut pemberhentian Presiden jika Presiden terbukti melakukan pelanggaran hukum-itupun dibatasi konstitusi). ${ }^{19}$ Diintrodusirnya hak-hak DPR dalam Pasal 20A UUD 1945 yaitu Hak Interpelasi, Hak Angket, Hak Menyatakan pendapat (sebelumnya di tingkat UU), dan hak anggota DPR meliputi; hak mengajukan pertanyaan, mengajukan usul dan pendapat serta hak imunitas maupun pertimbangan yang harus dimintakan pemerintah kepada DPR menyangkut pengangkatan Duta Besar, Penerimaan Duta Besar, Panglima TNI, Kepala Polri, Gubernur BI dan Deputi Gubernur, ${ }^{20}$ menjadikan posisi bargaining parlemen semakin kuat di depan pemerintah (belum lagi rencana penguatan DPR dalam revisi RUU Susduk yang sedang dibahas). Sayangnya pemahaman akan esensi sistem presidensiil tereduksi oleh semangat parlementarian dari parlemen-hingga kemudian terbentuk sebuah sistem presidensil yang tidak tegas, meminjam istilah Rocky Gerung telah terjadi “Konvensi Politik Parlementarian" ${ }^{21}$

Efektivitas fungsi pemerintahan menghendaki lembaga kepresidenan didukung oleh bekerjanya suatu sistem perwakilan yang efektif. Hubungan antara lembaga kepresidenan dan sistem perwakilan yang berimbang akan

${ }^{18}$ Sofian Efendi, "Sistem Pemerintahan Negara Kekeluargaan", dalam dikusi terbatas dengan Tema:"Nasionalisme, Pancasila dan Globalisasi", yang diselenggarakan oleh Nusantara Institute,Tanggal: 11 Maret 2008.

${ }^{19}$ Jimly Asshiddiqie, "Konstitusi \& Konstitusionalisme Indonesia", ctk pertama Jakarta, 2005, Kontitusi Press, hlm. 227-228.

${ }^{20}$ UUD 1945 Pasal 20A.

${ }^{21}$ Rocky Gerung,"Bersama Kita Bisa-Berpisah Sudah Biasa", Kompas 5 April 2008. 
meletakkan fondasi check and balances yang efektif ${ }^{22}$ Secara umum dapat dikatakan bahwa penguatan sistem pemerintahan presidensial membutuhkan penguatan lembaga kepresidenan, penguatan lembaga perwakilan, serta perimbangan hubungan kelembagaan antara presiden dan legislatif, hal tersebut untuk terciptanya sistem pemerintahan presidensial yang efektif. ${ }^{23}$

Sistem multipartai dan sistem presidensial merupakan dua sistem yang sulit digabungkan. ${ }^{24} \mathrm{Hal}$ ini setidaknya telah dibuktikan pada 31 negara yang masuk kategori demokrasi yang stabil-Syamsuddin Haris dari LIPI pernah menyampaikan bahwa gabungan sistem Presidensial dan sistem multipartai adalah "kawin paksa", tamsil terdekat adalah Filipina yang mempraktekkan Sistem Presidensial dan Multipartai-yang bisa kita lihat dan ukur tingkat efektifitas dan stabilitas politiknya ${ }^{25}$ (Filipina adalah salah satu negara yang paling sering mengalami Kudeta).

Setidaknya ada tiga alasan mengapa kombinasi ini menimbulkan permasalahan. Pertama, tidak adanya pemenang Pemilu Presiden dan Wakil Presiden yang mayoritas mutlak dalam legislatif ditambah dengan pembagian kekuasaan menimbulkan deadlock antara eksekutif dan legislatif. Kedua, tidak adanya suatu sistem pemilihan lembaga kepresidenan yang sesuai dengan paparan yang di atas. Ketiga, perlu dikaji peran dan fungsi berbagai elemen penunjang lembaga kepresidenan serta pembentukan struktur kelembagaan penunjang berdasarkan fungsi tersebut. ${ }^{26}$

Persoalan gabungan partai politik pendukung Presiden dan Wakil Presiden terpilih sebagaimana telah diarahkan oleh Undang-Undang Dasar 1945, secara teoretik mestinya dilanjutkan dengan formalisasi koalisi antara partai politik atau gabungan partai politik. Hal ini pun sekarang mengemuka seperti usulan partai Golkar melalui koalisi permanen, ${ }^{27}$ penting didorong agar pencalonan presiden dilakukan sebelum pemilu legislatif. Dengan demikian, partai-partai dirangsang berkoalisi karena platform perjuangan,

${ }^{22}$ Scott Mainwaring, "Presidentialism, Multipartism, and Democracy:The Difficult Combination," Comparative Political Studies, 26 (1993), hlm. 198-222.

${ }^{23}$ Carlos Pereira and Bernardo Mueller, "The Cost of Governing: Strategic Behavior of the President and Legislators in Brazil's Budgetary Process," Comparative Political Studies, Vol. 37, No. 7, September 2004, hlm. 781-815.

24. R.William Liddle and Saiful Mujani, "A New Multiparty Presidential Democracy", Asian Survey. Vol XLVI, No 1, January/February 2006 Press, Agustus 2006.

${ }^{25}$ M. Hernowo, “Langkah Hegemoni Parpol Besar", Kompas, Jumat, 14 Maret 2008.

${ }^{26}$ Matthew Soberg Shugart and John Carey, "Presidents and Assemblies", Cambridge: Cambridge University Press, 1992.

${ }^{27}$ Partai Golkar Rintis Koalisi Permanen, hlm. 2, Kompas, Jumat 4 April 2008. 
bukan karena kepentingan kekuasaan. Formalisme koalisi tersebut yang memiliki kader yang duduk dalam kabinet Presiden dan Wakil presiden terpilih. ${ }^{28}$ Koalisi ini diharapkan akan mencegah polarisasi dan fragmentasi berlebihan antara berbagai kekuatan yang ada. Koalisi yang demikian memberikan dukungan riil bagi penyelenggaraan pemerintahan secara lebih efektif dalam masa jabatan Presiden dan Wakil presiden. Bagi munculnya sebuah koalisi yang berarti maka faktor kepemimpinan dalam partai dan kedisiplinan partai menjadi kunci ${ }^{29}$ Karenanya adalah sesuatu yang mendesak untuk memperhatikan keterkaitan dan kalau perlu keberlanjutan koalisi antar partai sebelum dan setelah pemilihan presiden. ${ }^{30}$

Isu krusial yang perlu diselesaikan adalah tentang pelaksanaan Pilpres itu sendiri, selama ini berkembang 3 skenario mengenai hal itu yaitu (1) mendahulukan Pemilu Presiden daripada Pemilu Legislatif; (2) Pemilu Presiden dan Pemilu Legislatif dilaksanakan secara serentak; (3) Pemilu Legislatif lebih dahulu dilaksanakan daripada Pemilu Presiden dengan syarat perolehan suara atau kursi di Pemilu Legislatif dijadikan acuan. Semua varian tersebut memiliki kelebihan dan kekurangan, ketika pilihan kita untuk memperkuat sistem layak kiranya pilihan pertama atau kedua kita ajukan. Mengapa? Kesatuan antara partai pemenang pemilu presiden dan partai pemenang pemilu legislatif lebih bisa dipastikan bila pelaksanaan pemilu presiden didahulukan dari pemilu legislatif. pilihan ini akan memberi dampak "gerbong kereta" (bandwagon effect) pada pemilih. ${ }^{31}$

Karena perilaku pemilih di Indonesia (preferensi pemilih) masih terpengaruh pada figur/tokoh bukan terikat pada partai politik (pengalaman Pilpres 2004 menunjukkan hal tersebut), sesuatu yang tidak terjadi di negara yang demokrasinya mapan, di Amerika Serikat misalnya masyarakatnya sudah terbagi jelas menjadi dua kutub yaitu Kubu Demokrat dan Kubu Republik, yang diperebutkan kedua kubu tersebut adalah suara masyarakat yang belum menentukan pilihannya (independent vooters). ${ }^{32}$

\footnotetext{
${ }^{28}$ Jose Antonio Cheibub, “Minority Governments, Deadlock Situations, and the Survival of Presidential Democracies" Comparative Political Studies 35(3) (April 2003) 384-412, Sage Publications.

${ }^{29}$ Joe Foweraker, "Institutional Design, Party Systems, Governability:Differentiating the Presidential Regimes of Latin America", British Annal of Political Science 28 (4) (Oct. 1998) 656-674, Cambridge University Press, 1998.

${ }^{30}$ Ibid

${ }^{31}$ M. Qodari, "(Tak) Berharap pada UU Pemilu”, Kompas, Senin, 3 Maret 2008.

32. Bambang Cipto, "Politik E Pemerintahan Amerika", ctk pertama, Yogyakarta, 2003, Lingkaran, hlm. 37.
} 
Mengapa terjadi demikian-karena di AS sistem sudah terlembaga, artinya terlepas siapapun figur Capres dari Partai Republik atau Partai Demokrat sudah barang tentu kaum loyalis Republik maupun Demokrat akan memilih kandidat Presiden dari partainya (meskipun dalam perkembangan hal ini tidak terlalu mengikat, karena faktor pendidikan dan peningkatan kesadaran politik). Kita lihat proses Konvensi untuk Pilpres 2008, dimana Republik sudah menentukan calon yang akan maju pada pilpres di bulan November, yaitu John McCain, sedangkan Demokrat masih berkutat dengan pertarungan Barrack Obama dan Hillary Clinton. Opsi kedua dengan melaksanakan Pilpres bersamaan dengan Pemilu Legislatif, konstitusi tidak mengatur soal pelaksanaan pemilu presiden dan pemilu legislatif. Karena keduanya merupakan rezim pemilu, gabungan pelaksanaan keduanya akan lebih baik. Jika pemilu bisa digabungkan, akan terjadi korelasi antara preferensi pilihan rakyat terhadap partai politik dan presiden. Implikasi positifnya akan terjadi hubungan konstruktif antara parlemen dan pemerintah sebagai konsekuensi pemerintahan presidensial. ${ }^{33}$ Akan tetapi justru opsi ketiga yang telah dipilih dan dilaksanakan pada Pemilu 2004, opsi ini sedikit banyak mereduksi sistem presidensiil itu sendiri, bahkan mengaitkan antara hasil pemilihan anggota DPR dan persyaratan CapresWapres adalah pengingkaran terhadap UUD 1945 (inkonstitutional), dalam Pasal 6A ayat (2) UUD 1945 hanya membatasi antara partai politik peserta Pemilu dan Partai politik bukan peserta Pemilu. ${ }^{34}$ Meskipun banyak kalangan beranggapan untuk 2009 kita tetap dengan mekanisme Pilpres 2004, opsi mendahulukan Pilpres daripada Pemilu Legislatif maupun opsi melaksanakan Pilpres dan Pemilu legislatif secara serentak baru bisa kita laksanakan dalam Pemilu 2014 (tak kurang dari Akbar Tandjung menyuarakan hal tersebut).

Beberapa literatur menunjukkan adanya hubungan yang relatif konsisten antara sistem kepartaian dalam kaitannya dengan Pemilu Presiden dan Wakil Presiden dan sistem presidensial. Multipartai, terutama yang bersifat terfragmentasi, menyebabkan implikasi deadlock dan immobilism bagi sistem presidensial murni. ${ }^{35}$ Praktek di Indonesia menunjukkan hal itu, bagaimana sulitnya menjaga kesolidan dan keharmonisan Koalisi terutama

\footnotetext{
${ }^{33}$ Kompas' "Pemilu Diusulkan Dibarengkan" Rabu, 12 Maret 2008.

${ }^{34}$ Saldi Isra, "Dinamika Ketatanegaraan Masa Transisi 2002-2005", Padang, Andalas University Press, Agustus 2006, hlm. 90.

${ }^{35}$ Scott Mainwaring, Op.Cit.
} 
dalam relasi antara Pemerintah dan Parlemen, SBY mengalami hal itumeskipun ada faktor determinan lain menyangkut sikap politik SBY yang terlalu hati-hati, dan akomodatif serta hambatan psikologis politik melihat daya tawar JK (wakilnya) yang lebih besar.

Tawaran yang diberikan untuk memperkuat presidensial adalah dengan menyederhanakan jumlah partai. Wacana tentang penyederhanaan atau pengurangan jumlah partai politik di DPR sebenarnya sudah lama muncul. Ide itu pernah disampaikan tim dari Lembaga Ilmu Pengetahuan Indonesia atau LIPI untuk revisi paket undang-undang politik. tim dari LIPI antara lain mengusulkan adanya syarat calon presiden dan wakil presiden dalam Pemilu 2009, minimal diusung 25 persen suara di DPR ${ }^{36}$ bahkan Golkar mengusulkan angka 30 \% Suara DPR. Dengan peraturan itu diharapkan muncul dua koalisi partai yang sifatnya permanen di parlemen, yaitu yang mendukung dan beroposisi kepada pemerintah.

Keadaan ini diharapkan dapat membuat pemerintahan bekerja lebih efektif karena mendapat dukungan yang kuat dan pasti dari sebagian anggota parlemen. Memang tawaran tersebut akan melahirkan pro dan kontra, di tengah positioning partai politik yang semakin ditinggalkan khalayak akibat ulah dari elitnya (masyarakat banyak yang tidak mengetahui kinerja partai, tetapi mereka masih percaya pada instrumen partai? Fungsi dasar sebagai agregator dan artikulasi kepentingan masyarakat, kelemahan administrasi organisasi juga menjadi kelemahan mendasar bagi partai politik) banyak hasil survei dari lembaga riset politik mendukung hal tersebut. Apakah bijaksana pintu untuk Capres hanya dibuka untuk partai-partai besar, seharusnya pintu diperluas-atau setidaknya syarat pencalonan dalam rentang 15-20\% (seperti dalam UU Pilpres 23 Tahun 2003) ${ }^{37}$ masih dipertahankan karena akan memunculkan varian pilihan bagi pemilih untuk kandidat Capres-Cawapres yang layak untuk dipilih.

Untuk dapat menghasilkan tipe sistem kepartaian sederhana, maka perlu pengkondisian dalam proses pemilu. Untuk dapat mengikuti pemilu berikutnya biasanya diberikan syarat minimal suara atau electoral thresholdmaka pemberlakuan Electoral Treshold sebesar 3 \% dan Parlementary Treshold sebesar 2,5\% untuk Pemilu 2009 dalam UU No. 10 Tentang Pemilu Legislatif ${ }^{38}$

\footnotetext{
${ }^{36}$ Kompas,"Langkah Hegemoni Parpol Besar", Jumat, 14 Maret 2008.

${ }^{37}$ UU Pilpres 23 Tahun 2003(bandingkan dengan RUU Pilpres yang sedang dibahas di DPR).

${ }^{38}$ UU No. 10 Tahun 2008 Tentang Pemilu DPR, DPD, dan DPRD.
} 
patut didukung, asalkan hal tersebut dipraktekkan secara konsisten. Sayangnya penerapan pemberlakuan ET dan PT hanya pada tingkat DPRtidak untuk DPRD Propinsi maupun DPRD Kabupaten/Kota. Artinya, meski tidak punya kursi di parlemen pusat, partai-partai "kecil" tetap punya kursi di parlemen daerah. Kursi di daerah ini meminjam istilah Muhammad Qodari akan menjadi "ventilator" yang memperpanjang usia 'partai-partai gurem', sehingga tujuan penyederhanaan partai politik akan sia-sia. ${ }^{39}$

Di Indonesia ET yang seharusnya imperatif ${ }^{40}$ bagi Parpol oleh Pemerintah disimpangi dengan terus membuka kran terbentuknya Parpol baru, hal ini ditambah dengan sikap parpol yang menyiasati aturan tersebut (banyak Parpol yang sekedar ganti "nama" dengan masih mengkaitkan dengan identitas parpol lama, Partai Bulan Bintang yang tidak memenuhi ET ganti nama menjadi Partai Bintang Bulan, meskipun akhirnya tertolong dengan aturan peralihan pasal 316 UU No. 10 Tahun 2008 tentang Pemilu). Seharusnya jika konsisten penerapan ET akan mengkonsolidasikan Parpol yang ada, Parpol-parpol yang tidak menembus ET dilarang mengikuti pemilu dan diarahkan untuk bergabung (baik dengan yang memenuhi ET maupun yang sama-sama tidak memenuhi ET), meskipun usul tersebut ekstrem bagi kalangan Parpol dan melahirkan pro-kontra, namun regulasi ini diyakini akan menuju ke upaya penyederhanaan partai.

Pengalaman Pemilu 1999 dan 2004 menunjukkan hal tersebut, dari 48 Partai sebagai peserta pada Pemilu 1999 menjadi 24 pada Pemilu 2004, kita bisa tarik benang merah diantara sekian parpol yang survive dan memiliki captive market tertentu hanya beberapa parpol saja. Ramlan Surbakti, guru besar FISIP Unair (mantan anggota KPU) dalam sebuah forum diskusi yang digagas Forum Rektor Indonesia simpul Jatim, menyimpulkan bahwa penggabungan parpol mutlak diperlukan melihat derajat kelembagaan parpol di Indonesia masih rendah. Hal itu dilihat dari empat hal, yakni kompetisi antarparpol, bentuk kompetisi antarpartai, jarak ideologi antarpartai, dan mengakarnya partai pada masyarakat. ${ }^{41}$

Kalau tidak kita terapkan penyederhanaan partai-sampai kapan kita akan "terjebak" dalam arus multipartai yang ekstrem seperti sekarang? Dalih Indonesia masih dalam era transisi demokrasi sering dijadikan alasan klasik oleh kalangan parpol (tesis Huntington, sebuah negara untuk

\footnotetext{
${ }^{39}$ M. Qodari, Op.Cit.

${ }^{40}$ Saldi Isra,"Menimbang Kembali Electoral Treshold" hlm. 60.

${ }^{41}$ Kompas, 18/12/07
} 
lepas dari era transisi membutuhkan $2 \mathrm{X}$ pemilu yang demokratis), meskipun sebenarnya ada dalih lain yang oleh alasan tersebut-parpol diyakini masih menjadi kendaraan efektif untuk meneguk kekuasaanapalagi parpol di Indonesia masih mendapatkan asupan susu dari Pemerintah melalui bantuan dana-yang menjadikan parpol tidak pernah mandiri, maka tak heran kaum "borjuasi" ramai-ramai terjun ke gelanggang politik-baik dengan membuat partai ataupun menguasai partai yang sudah ada. Hal ini jika tidak dikelola secara baik akan mengancam demokrasi itu sendiri, diharapkan di kemudian hari para "pemilik modal" dapat memfokuskan dirinya dalam upaya pemberdayaan masyarakat dan perbaikan kualitas kehidupan bangsa melalui cara-cara yang lebih efektif dan down to earth di luar partai politik. ${ }^{42}$

Belum lama Jusuf Kalla sering menuduh demokrasi tidak efektif dan inefisien. Biaya demokrasi terlalu mahal. Pemilu legislatif harus bersamaan dengan pemilu eksekutif. Kalau bisa, pemilihan kepala daerah digelar serentak. Demokrasi bukan tujuan, melainkan alat mencapai tujuan. Ironis ketika demokrasi dihitung dengan neraca laba rugi. Demokrasi tidak lagi dilihat sebagai sebuah proses tapi alat, bahkan doktrin Kalla meminjam istilah Indra J Piliang ${ }^{43}$ telah banyak diikuti dan diamini kalangan sipil, misalnya PBNU mengusulkan Pilkada dikembalikan pada pilihan di DPRD-dengan alasan melihat banyaknya konflik pilkada, belum lagi Lemhanas mengusulkan agar Gubernur ditunjuk saja oleh Pemerintah pusat. Ongkos demokrasi memang mahal tapi dengan dangkal menyalahkan demokrasi sebagai penyebab dari kekarutan adalah tidak bijaksana terlebih dengan menarik kembali esensi dari demokrasi-yaitu adanya kontrak sosial langsung antara rakyat dan penerima mandat. Kita sudah terlalu lelah dan penat akan praktek penyimpangan di era Demokrasi Terpimpinnya-Soekarno maupun Demokrasi PancasilanyaSoeharto, saatnya kita menerapkan demokrasi secara subtantif-demokrasi. Menurut Sir Winston Churchill adalah sistem terburuk-tapi sampai sekarang tidak ada sistem yang lebih baik dari demokrasi.

Noda lain yang kasat mata adalah adanya aturan peralihan dalam pasal 316 UU No. 10 Tentang Pemilu yang menyatakan semua parpol yang memiliki kursi di parlemen-dapat mengikuti pemilu 2009. Hal ini tentu sangat merugikan 8 partai politik peserta Pemilu 2004 yang tidak

\footnotetext{
${ }^{42}$ Firman Noor," Penyederhanaan Partai", 1 Maret 2008.

${ }^{43}$ Indra Jaya Piliang, “Kalau Bukan Demokrasi, Apa?”, TEMPO, 26 Desember 2007.
} 
memiliki kursi di DPR, hal ini mengulangi pengalaman pemilu 1999 dan 2004 yang mensyaratkan electorald treshold $2 \%$ dan $3 \%$ tapi dalam praktek tidak diterapkan secara tegas. Munculnya pasal ini ditenggarai adalah sebagai "trade off" antar kekuatan parlemen, pasal ini ditukar dengan kebijakan perubahan dapil dan kursi serta penarikan sisa suara ke propinsi yang didukung partai-partai besar di parlemen yang dipastikan akan mengaburkan akuntabilitas suara dan kursi yang diperoleh.

\section{Penutup}

Problem sistem presidensiil dan praktek parlementarian dengan kekarutan multi partai majemuk ekstrem yang ada dapat diselesaikan dengan berbagai langkah; Pertama, ketika sistem presidensiil telah menjadi amanat konstitusi maka segala konvensi praktek parlementarian harus dihentikan, hubungan Pemerintah dan Parlemen dikembalikan dalam kerangka checks and balances, jika solusi untuk mendudukkan relasi fungsi kelembagaan adalah melalui amandemen-maka amandemen ke 5 patut untuk didorong keinginan DPD dan Presiden untuk mengamandemen UUD 1945 memperlihatkan hal tersebut, namun momentum pasca Pemilu 2009 lebih tepat, agar amandemen jauh dari kepentingan jangka pendek.

Hal lain yang perlu dilakukan adalah merubah sikap-perilaku partai politik yang sudah terjangkit virus parlementarian, pembentukan kabinet bayangan (shadow cabinet) di Parlemen oleh politikus muda adalah salah satu contohnya, kabinet bayangan mafhum di sistem parlementer dan biasa dijadikan instrumen partai oposisi di parlemen sebagai penyusunan kebijakan partai.

Kedua, dengan dipilihnya sistem Presidensiil maka penyederhanaan partai mutlak diperlukan, tidak mungkin sistem presidensiil ditopang dengan multi partai yang ultra majemuk, praktek di negara yang demokrasinya stabil tidak mengawinkan sitem multipartai dan presidensiil, maka penerapan ET da PT sebesar 3\% dan 2,5 \% dalam UU Pemilu patut didukung dan diterapkan secara konsisten, tidak mungkin kita satu sisi menginginkan penyederhanaan partai-tapi di sisi yang lain kran untuk berdirinya partai politik baru terus kita buka, untuk konteks Indonesia format multi partai sederhana yang tepat untuk diterapkan;

Ketiga, format koalisi yang ada selama ini perlu diubah, untuk memperkuat sistem presidensiil-koalisi harus permanen dan dibentuk sebelum pemilu legislatif (perlu dimasukkan dalam RUU Pilpres), karena 
hal ini akan mengikat dan mendisiplinkan partai peserta koalisi, koalisi dibangun berdasarkan platform perjuangan dan visi bersama, koalisi tidak dibentuk untuk mengakomodasi semua representasi politik, tapi yang dibutuhkan adalah koalisi yang smurf dan lincah dalam mengeksekusi kebijakan, dan hal ini tentu membutuhkan dukungan pemerintahan (governing support) di parlemen, hal tersebut juga bisa disupport ketika UU Kementerian Negara segera dibahas dan disahkan-karena hal ini akan menjadi kerangka penyusunan kabinet, sehingga presiden tidak terus dirongrong kepentingan representasi parpol-tapi mengisi kabinet dengan orang yang capable-bermoral;

Ke depan, diharapkan Republik ini mempunyai Presiden yang tidak "terlalu banyak" pertimbangan dan kalkulasi dalam merumuskan kebijakan politiknya, khususnya mempertimbangkan sekutu politiknya, sementara dirinya merupakan produk legalitas mandat rakyat secara langsung, ketika itu terjadi bukan sistem yang dipersalahkan-tapi mungkin kita telah salah memberikan mandat (ke Presiden), meminjam kata-kata Marsilam Simanjuntak: "Pekerjaan Pemerintah (baca: Presiden) itu adalah membuat keputusan dan menjalankannya dengan konsekuen"[.]

\section{Daftar Pustaka}

Arend Lipjhart, ed,"Parliamentarism versus Presidential Government" (Oxford: Oxford University-Press,1992.

Bambang Cipto, "Politik E Pemerintahan Amerika", ctk pertama, Lingkaran, Yogyakarta,2003.

Bantarto Bandoro, J.Kristiadi, Mari Pangestu dan Onny S.Prijono (penyunting),"Refleksi Setengah Abad Kemerdekaan Indonesia", Ctk. Pertama, CSIS, Jakarta, 1995.

Ign Ismanto, J.Kristiadi, Indra J.Piliang (et al) ; Penyunting T.A Legowo, Y.Subagyo, Sutomo (et al), "Pemilihan Presiden Secara Langsung 2004; Dokumentasi, Analisis dan Kritik" ctk pertama Jakarta :Kedeputian Dinamika Masyarakat Menristek RI, 2005 Kerjasama dengan Departemen Politik dan Perubahan Sosial CSIS.

J.D. Legge, "Kaum Intelektual dan Perjuangan Kemerdekaan: Peranan Kelompok Sjahrir", hal 179-182, Jakarta, Pustaka Utama Grafiti, 1993.

Matthew Soberg Sughart dan John M Carey,"President and Asembly: Constitutional Design and Electoral Dynamics", Cambridge Unversity Press, 1992. 
Jimly Asshiddiqie, "Konstitusi E Konstitusionalisme Indonesia", ctk. pertama Jakarta, 2005, Kontitusi Press.

Joe Foweraker, "Institutional Design, Party Systems, Governability: Differentiating the Presidential Regimes of Latin America", British Annal of Political Science 28 (4) (Oct. 1998), Cambridge University Press, 1998.

Jose Antonio Cheibub, "Minority Governments, Deadlock Situations, and the Survival of Presidential Democracies" Comparative Political Studies 35(3) (April 2003), Sage Publications.

M. Rusli Karim,"Perjalanan Partai Politik Di Indonesia; Sebuah Potret Pasang Surut",Ctk 3, Jakarta;Rajawali Press.

Matthew Soberg Shugart and John Carey,"Presidents and Assemblies", Cambridge: Cambridge University Press, 1992.

Saldi Isra, "Dinamika Ketatanegaraan Masa Transisi 2002-2005", Padang, Andalas University Press, Agustus 2006.

Scott Mainwaring,"Presidentialism, Multipartism, and Democracy:The Difficult Combination",Comparative Political Studies, 26 (1993).

Tim Litbang Kompas-Ed. Pemilu, "Partai-partai Politik Indonesia : Ideologi, Strategi dan Program", cet.1.-Jakarta : Kompas, 1999.

William R Thomson dan Monte Palmer,"The Comparative analysis of Politics", 1978.

Abdul Gaffar Karim, "Kabinet Bayangan" , 7/09/2007.

Carlos Pereira and Bernardo Mueller, "The Cost of Governing: Strategic Behavior of the President andLegislators in Brazil's Budgetary Process," Comparative Political Studies, Vol. 37, No. 7, September 2004, 781-815.

G. Bingham Powell, Jr., Contemporary Democracies, dalam jurnal Dephan "Indikator Sistem Politik Demokratis" 2002.

R. William Liddle and Saiful Mujani, "A New Multiparty Presidential Democracy", Asian Survey. Vol XLVI, No 1, January/February 2006 Press, Agustus 2006 dalam Skripsi Sexio Yuni Noor Sidqi "Partai Politik dan Transisi Demokrasi di Indonesia (Studi Perkembangan Partai Politik dari era Orde Baru-Reformasi)",2005, FH-UII)

Lance Castles, "Pengalaman Demokrasi Liberal di Indonesia”, (1950-1959) dalam Seminar "Pendidikan Demokrasi dan Dialog Sipil-Militer", Tanggal 11 Juni 1998

Prof Dr Sofian Efendi, "Sistem Pemerintahan Negara Kekeluargaan", dalam dikusi terbatas dengan Tema:"Nasionalisme, Pancasila dan Globalisasi", yang diselenggarakan oleh Nusantara Institute, Tanggal: 11 Mar 2008.

UUD 1945 (Hasil Amandemen 1999-2002) 
UUDS 1950

UU Pilpres 23 Tahun 2003

UU No. 10 Tentang Pemilu DPR, DPD, dan DPRD.

Kompas, 17 September 2004

Kompas, 18 Desember 2007.

Kompas, 1 Maret 2008.

Kompas, 3 Maret 2008.

Kompas, 12 Maret 2008.

Kompas, 14 Maret 2008.

Kompas, 17 Maret 2008.

Kompas, 4 April 2008.

Kompas 5 April 2008.

Kompas, 12 Mei 2008.

TEMPO, 26 Desember 2007.

A Rahman Tolleng, ,'What Next Hubungan Eksekutif-Legislatif ?",\# posted dari www. Fordem.org :15.05.05, 22.45 Wib.

Sexio Yuni Noor Sidqi "Partai Politik dan Transisi Demokrasi di Indonesia (Studi PerkembanganPartai Politik dari era Orde Baru-Reformasi)", Skripsi, 2005, FH-UII). 